\title{
Bancassurance: Challenges and Opportunities in Republic of Serbia
}

\author{
Ivana Marinović Matović \\ Addiko BankAD Belgrade, Serbia, ivana.m.matovic@gmail.com
}

\begin{abstract}
Bancassurance is not just a sale of insurance products at bank counters, but a complex cooperation involving both partners in the project realization, with the goal of satisfying their own interests as well as clients' interests. In the Republic of Serbia, banks began to deal with insurance activities in 2007. Since then, the sale of insurance products through banks has been constantly growing. The paper will present the current bancassurance models in the Republic of Serbia: integral distribution; expert distribution and combined distribution. The paper will present the comprehensive condition of bancassurance in the Republic of Serbia, above all the legal framework of the bancassurance concept; activities necessary for the successful implementation of bancassurance; market participants; competition among banking products and insurance products; the current level of cooperation between banks and insurance companies. Participants in the insurance market established by the Republic of Serbia, such as the National Mortgage Insurance Corporation, the Serbian Export Credit and Insurance Agency and the Deposit Insurance Agency, will be presented in paper, with an overview of the advantages and disadvantages of state insurance regulations. By gathering facts and data based on available literature and public databases, the current state of the insurance market and the possibilities for further development of bancassurance in the Republic of Serbia will be determined. The choice of a bancassurance model is essential for the successful functioning of the overall concept and its long-term sustainability in a dynamic business environment. The paper points to the fact that by designing an adequate bancassurance model, there may be a significant development of the Serbian financial services market.
\end{abstract}

KEYWORDS: Bancassurance, Insurance, Banking, Financial services, Republic of Serbia

\section{Introduction}

In the financial services sector, there are major changes that are aimed at increasing profits and fighting for a share of the world market. One of the changes is related to linking banks and insurance organizations. The process of integrated market performance of banks and insurance companies is known as Bancassurance. Bancassurance covers a wide range of detailed contractual relationships between banks and insurance companies.

The effectiveness of the bancassurance concept depends on the determination of the participants to develop this sales channel, identifying their individual strengths and weaknesses in order to develop an effective joint market appearance, as well as the continuing presence of both partners (Bergendahl 1995). World experience in the bancassurance development points to the fact that it took several years from the introduction of this concept until it became a profitable channel for the sale of insurance products. Bancassurance, as a channel for the distribution of insurance products, will gain more and more importance in the next period, with an unknown future form of appearance.

\section{Current bancassurance models in the Republic of Serbia}

The 2005 Law on Banks (Official Gazette RS, 2005) explicitly allowed banks in the Republic of Serbia to deal with insurance activities. According to the 2005 Law on Banks, a commercial bank may appear in a triple role: (a) as an insurance agent - a bancassurance, (b) an insured person, and (c) an insurance user. However, banks entered the insurance sector at the end of 2006 or early 2007 when there were only five banks in the network of insurance services. Their number has been growing from year to year, so there are 18 banks in the Republic of Serbia, licensed to carry out insurance advocacy activities (NBS, Insurance sector in Serbia 2018).

In the Republic of Serbia there are solid capacities to conduct sales of insurance through bancassurance, although the achieved premium has not been satisfactory, which is justified by the 
lack of adequate demand. The history of the bancassurance development shows that at the very beginning of the institutionalization of this channel of insurance sales with banks, the prevailing attitude was that bancassurance is a low-profit job, that users have no significant interest in various types of insurance offered, that insurance companies are oriented towards their sales network. Because of this, the banks did not show any increased interest in the development of bancassurance.

There are several motives for the bancassurance development (Krstić, et al. 2011), such as better positioning in the market in relation to competition, in the conditions of constant innovations, interest to provide the client with a complete package of financial services in one place, increasing customer loyalty by mid- or long-term bonding based on the purchase of life insurance in the bank; better utilization of capacities and increase of productivity of permanently employed staff, increase in profit from intermediary fees, better quality of loans by insuring collateral against different risks during the term of the loan by banks. Intensified bancassurance development in Serbian commercial banks is still expected.

The bancassurance concept as the distribution of specially designed products of life and nonlife insurance, adjusted for sales through the banking network in the Republic of Serbia, is realized in two phases (Munich Re 2001). The first phase is characterized by a combination of sales of banking and insurance products or the sale of simpler insurance products (travel health insurance, casco insurance, supplementary health insurance, household insurance, etc.), although the best results are achieved through the integration of banking and insurance products. The specificity of the second phase is the direct sale of insurance products by banking officers, independent of banking products (Colaert 2015). Namely, it is logical that after getting to know and practicing the sale of simple insurance products in a bank, alone or in a package with banking products, most of the insurers start selling more complex insurance products that are sold independently of banking products (life insurance, supplementary insurance against the occurrence of an accident, the serious illnesses and coverage of treatment costs, voluntary pension insurance, income insurance, etc.).

If we compare the bancassurance of the Republic of Serbia and European countries, the most important difference is the fact that non-life insurance products are better sold through banks in relation to life insurance products. In cooperation with banks, insurance companies have access to a large number of clients and the possibility of offering them different types of simple non-life insurance products such as casco insurance, home insurance, travel health insurance, whose sales are mostly related to the sale of payment cards. The middle class of the population in the Republic of Serbia has been significantly reduced as a result of war events, bad privatizations and other transitional events, so the insurance comes down to the compulsory insurance policy. In addition, in the past period, banks have used higher demand for loans and, in cooperation with insurance companies, they have begun to conclude policies for securing the collection of loans in the event of certain risks (insurance of credit products in the event of death due to accident, illness, work loss). In this respect, in banks, the sale of insurance is mainly reduced to the sale of packages of bank products with included insurance, which does not require a large sales effort of employees.

In the Republic of Serbia, life insurance products through bancassurance are less sold as stand-alone products due to numerous factors such as low living standards and citizens' distrust of long-term savings. The only product in the field of life insurance that is freely sold through this channel is "Credit Life", in banks in which it is obligated to insure housing loan. With an average of 14 Eur per capita allocated to life insurance in 2012, the Republic of Serbia is at the bottom of the surrounding countries (GSI Master 2015). Learned by the experience of foreign companies, it is assumed that citizens would be more interested if they would get explanation in simple terms regarding the most important characteristics of life insurance and all the benefits that such a type of savings provides. Such explanations can be largely presented by banking officials, bearing in mind that citizens have greater confidence in them, in relation to traditional insurance agents.

Non-life insurance consists of 18 different subgroups, each with several types of insurance (European Commission 2017). In the Republic of Serbia, banks in cooperation with insurance companies, in the package with basic retail banking products (current accounts, payment cards, loans) offer the following non-life insurance products (Božović, et al. 2014): 
- Insurance assistance on the road in the country and abroad

- Travel health insurance

- Household insurance

- Car insurance

- Voluntary supplementary health insurance - in case of severe illnesses and surgical interventions

- Accident insurance for household members - in case of death due to an accident or illness, as well as permanent disability injuries

- Insurance of credit card users from consequences of an accident

- Credit insurance - ensuring the regular repayment of loans in use in certain cases

- Insurance against financial losses of payment card users

According to the NBS data in the Republic of Serbia, the share of non-life insurance premium in the total insurance premium is dominant. In Serbian commercial banks, mostly sold non-life insurance is credit insurance (NBS, Insurance sector in Serbia 2018).

From the moment of the institutionalization of bancassurance in the Republic of Serbia, the nominal premium insurance realized by this channel has grown (Table 1). As presented in Table 1, the share of insurance premiums generated by bancassurance in the total premium amounted to $1.16 \%$ in 2010 , and to $3.40 \%$ in 2015 .

Table 1. Share of insurance premiums generated by bancassurance in the total premium in 000 RSD (2010-2015)

\begin{tabular}{|l|l|l|l|l|l|l|}
\hline Insurance premium & $\mathbf{2 0 1 0}$ & $\mathbf{2 0 1 1}$ & $\mathbf{2 0 1 2}$ & $\mathbf{2 0 1 3}$ & $\mathbf{2 0 1 4}$ & $\mathbf{2 0 1 5}$ \\
\hline Life insurance premium & 9.352 .714 & 9.992 .706 & 11.855 .400 & 14.065 .458 & 16.714 .878 & 19.364 .297 \\
\hline $\begin{array}{l}\text { Non-life insurance } \\
\text { premium }\end{array}$ & 47.168 .218 & 47.321 .292 & 49.608 .308 & 49.976 .051 & 55.768 .774 & 61.561 .497 \\
\hline Total premium & 56.520 .932 & 57.313 .998 & 61.463 .708 & 64.041 .509 & 72.483 .652 & 80.925 .794 \\
\hline $\begin{array}{l}\text { Insurance premiums } \\
\text { generated by bancassurance }\end{array}$ & 658.194 & 1.019 .106 & 1.318 .448 & 2.076 .589 & 2.415 .124 & 2.753 .659 \\
\hline Share in the total premium & $1,16 \%$ & $1,78 \%$ & $2,15 \%$ & $3,24 \%$ & $3,33 \%$ & $3,40 \%$ \\
\hline
\end{tabular}

Source: NBS, Supervisory Board of Financial Institutions, Sector for Supervision of the Performance of Insurance Activities, https://www.nbs.rs/internet/cirilica/60/60_2/index.html

The bulk of the bancassurance premium in 2015 was realized by selling life insurance. In the total premium achieved through the sale of life insurance, the premium realized through bancassurance participated with $14.22 \%$, while in the premium of life insurance realized through the agent participated with $41.51 \%$ (NBS, Supervisory Board of Financial Institutions, 2016). The premium of bancassurance in selling non-life insurance products is far less. In the framework of non-life insurance, the largest premium was secured by the sale of insurance policies from the consequences of the accident, insurance of loan collection and travel assistance.

Insurance claims by state agencies in the Republic of Serbia represent a form of direct state participation in the insurance sector (Njegomir \& Maksimović, 2009). The argument in support of the thesis on the justification of the establishment of state agencies in the field of insurance claims is the assistance to exporters in conquering new markets, as they are specialized institutions that have more detailed information about foreign markets and potential partners. For this purpose, the Agency for Insurance and Financing of Exports of the Republic of Serbia (AOFI), as the official export credit agency of the Republic of Serbia, was established by a special Law, for the purpose of stimulating and improving the export and development of economic relations with foreign countries (https://www.aofi.rs/en/). The activities of AOFI are the insurance and financing of exports for Serbian export-oriented companies. 
The insurance of housing loans in the Republic of Serbia through a state agency established for this purpose has largely contributed to the increase in the credit activity of commercial banks in connection with the housing loans (having in mind the reduction of collection risk). Given that at the time of the emergence of housing loans in the banking market of the Republic of Serbia there were no interest of insurance companies to enter into this type of arrangement with commercial banks, the National Mortgage Insurance Corporation (NKOSK) emerged as the only option of that kind which significantly contributed increasing the housing credit activity of banks (http://www.nkosk.rs/en). NKOSK was established in 2004 on the basis of the Law on the National Mortgage Insurance Corporation (Official Gazette RS, 2004). The Republic of Serbia participates in the insurance field also through the Deposit Insurance Agency (DIA), which performs mandatory deposit insurance activities, in accordance with the Deposit Insurance Act (http://www.aod.rs/enindex.html\#!). The secured amount of the deposit is up to 50,000 Eur in RSD equivalent at the official middle exchange rate of the National Bank of Serbia, valid on the day when the decision of the competent court on the bankruptcy or liquidation procedure in the bank.

Considering that the insurance market is slowly opening up in the Republic of Serbia for other participants, in addition to the state agencies that have had an absolute primacy until now, the possibility for a significant development of the bancassurance is created. In the coming years, banks will not be able to do business positively if they do not include the sale of insurance in their offer. Bancassurance as a sales channel can, in due course, become the dominant channel for life insurance policies, what is the practice in many EU countries, such as Italy and France, but it is necessary for the management of the bank to know and recognize it (Krstić, et al., 2011). Banking that enables direct communication with clients, insight into their financial situation and financial advising, put the banks in an ideal position to present and sell more complex products to their customers.

\section{Possibilities for further development of bancassurance in the Republic of Serbia}

The preconditions for the further development of bancassurance in the Republic of Serbia are numerous. The most significant are long-term partnership between the bank and the insurance company; and understanding the importance of the bancassurance project by the management of the bank and the insurance company. In that sense, it is necessary to joint efforts, define and implement activities aimed at continuous implementation of the bancassurance in the existing banking system, in order to create a self-sustainable and highly profitable business that will benefit all the participants in the project. In the process of cooperation, different sales strategy models should be developed by defining the type of cooperation, distribution channels, offers, methods of advertising, defining a system of cross-selling banking products and insurance products. The preconditions (Krstić, et al. 2011) for the further development of bancassurance would be creation of specialized products of bancassurance, fully adapted to distribution through a bank network and adapted to the needs of bank clients; the existence of IT support at all stages of the implementation of the bancassurance; access from every computer in the bank network; a system of continuous and interactive training for developing sales and communication skills of bank employees in order to qualify for efficient sales of insurance products as stand-alone products; the rewarding of bank employees and encouraging competitive spirit of the bancassurance sales force.

In most European countries, bancassurance has proven to be the most productive channel for the sale of life insurance, primarily because of compatibility with traditional bank deposit products (Buric, at al. 2015). In order to ensure a significant increase in the life insurance premiums, and therefore total revenues from fees and commissions, it is necessary (Schlag 2003) to transfer a households' deposits into life insurance premiums, to increase of life insurance premiums, to increase the bank provision for representation in the life insurance sale.

Intensified development and application of bancassurance in Serbian banks is still expected. This is reinforced by the fact that banks intention is to significantly increase fee and commission income in order to reduce the dependence on interest margins, as well as the tendency to increase the productivity of permanently employed staff, bearing in mind the large share of sallary costs in 
bank operating expenditures. One of the reasons why the sale of insurance through banks is of importance is a higher degree of trust in a banking advisor than in a insurance agent (Nissim 2010). The success of bancassurance requires changing the working culture of employees both in banks and insurance companies, as well as applying a more flexible employee reward system. Insurance sales is generally difficult, especially in the Republic of Serbia, faced with low living standard and an insufficient culture of insurance. Insurance companies sell an intangible product whose usefulness can not be measured immediately, but its positive features can be felt in the future. Bearing in mind the many difficulties encountered by insurance sales, there are a significant number of insurance agents who quickly give up the further work. Special attention should be paid to the improvement of sales skills, especially the communication skills of bank employees, which should be adjusted to the specifics of insurance sales. In addition to the above, the limiting factors that need to be addressed in the coming period are (Ostojić 2014): the lack of top-level education and continuous training of bank employees; lack of a culture of selling insurance products within the bank; poor knowledge of managers, initially negative attitude of employees towards insurance; insufficient product promotion as a result of inadequate marketing strategy; the lack of personalized services in a time appropriate to the client; lack of time since busy customers do not have time to listen and discuss buying insurance; reduced number of customers due to the increasing use of electronic banking.

The success of bancassurance requires changing the way of thinking and organizational culture of employees in both banks and insurance companies. However, encouragung is the fact that banks have established long-term relationships with their clients and deepening these relationships over time. This fact can help banks to provide their customers with additional products and services beyond classic banking ones, with no major resistance. The current level of bancassurance development in the Republic of Serbia, is dependant on insufficiently attractive rewarding system for the bank employees who are in charge of implementation of this sales channel. In contemporary banking, a number of clients migrated to banking digital channels, using the Internet, social networks and electronic banking products. In addition, a large number of clients still need to come to the bank to settle a specific request or simply do a payment transaction. In that sense, the branch offices are still the most important communication channels. The largest number of contacts with clients is realized by the cashiers in the branch office. Therefore, the biggest opportunity for a client entering the bank to purchase one of the insurance products is created at the cash desk. In most banks, cashiers can not sell insurance products since they are not licensed, but they can direct the client towards a licensed advisor. Therefore, it is important to set up a clearly defined and stimulating reward system that equally motivates all employees in the bank involved in the sale of insurance products.

Banks, as agents in the sale of insurance, due to the great potential that they provide as a distribution channel, should try to increase contracted fees, especially in the part of life insurance sales, where their biggest contribution is expected. In most Serbian commercial banks that have concluded agreements with certain insurance companies, employees are not sufficiently stimulated for the same level of sales as employees in other sales channels (employees in insurance companies, brokerage companies). In this way, the amount of fee from insurance companies, together with a higher volume of sales on the basis of the deposit transfer into life insurance, will enable monetary rewards to all employees in banks participating in insurance sales. This will further contribute to the increased number of life insurance policies, and thus to the higher income of both banks and insurance companies.

\section{Conclusion}

Bancassurance represents the sale of products and services by banks and insurance companies by the same source or using the same client base. Bancassurance has become a key distribution channel in many global insurance markets over the last two decades. Despite the significant number of commercial banks that are insurance agents of the leading insurance companies in the Republic of Serbia, despite the good conditions regarding the large number of licensed banking employees as insurance agents, a wide 
network of branches, and a large client base; the bancassurance in the Republic of Serbia is at the initial level of development, based on the share of insurance premiums sold through banks in the total sold premiums.

The dominant opinion in the Serbian commercial banks was that interest margins were still high and that bancassurance was a low-profitable business, which led the banks' management to show no greater interest in the development of this sales channel. Banks ware selling packages of banking products with included insurance, but not insurance alone. However, in order to increase the profitability, the Serbian commercial banks will increasingly be opting for the development of non-interest bearing products and services in order to increase revenues from fees and commissions and reduce the dependence on interest income. Through the bancassurance concept, the needs of a contemporary, increasingly demanding potential client can be fully met, easing the fast business rhythm with the possibility of integrated purchasing of various financial services.

Intensified development and application of bancassurance in Serbian commercial banks is still expected. The basis for the further development is the desire of banks to significantly increase fee and commission income in order to reduce the dependence on interest margins and all the risks they bear, as well as the tendency to increase the productivity of permanently employed staff, bearing in mind the large share of sallary costs in bank operating expenditures.

Bancassurance can become a driver of development of the financial sector in the Republic of Serbia, since through this sales channel, and continuous cooperation and adaptation of both partners, they can improve the existing services and introduce new ones in line with market requirements.

\section{References}

Bergendahl, G. 1995. "The profitability of Bancassurance for European banks." International Journal of Bank Marketing 13, pp.17-29.

Božović, J., Saračević, M., Milošević, A. 2014. “Insurance Distribution Channels in Serbia.” Ekonomika 60, 2014, № 4 (oct-dec): 105-116.

Buric, M.N., Kascelan, V., Vujosevic, S. 2015. "Bancassurance Concept from the Perspective of Montenegrin Market." Economic Review: Journal of Economics and Business 13(2): 62-73.

Colaert, V. 2015. "European Banking, Securities and Insurance Law: Cutting Through Sectoral Lines?" Common Market Law Review 52: 1579-1616.

Deposit Insurance Agency (DIA). n.d. Available at http://www.aod.rs/en-index.html\#!

European Commission. 2017. "Study on consumers' decision making in insurance services: a behavioral economics perspective.” Accessed 02.05.2019, retrieved from https://ec.europa.eu/newsroom/document.cfm?doc_id=46972.

GSI Master d.o.o. 2015. “Životno osiguranje u razvijenim zemljama sveta i kod nas.” Accessed 01.05.2019. $\mathrm{http} / /$ gsimaster.rs/index.php?option=com_content\&view=category\&layout=blog\&id=74\&Itemid=68. Insurance\%20Companies\%20\%20Final.pdf.

Krstić, B., Vojvodić-Miljković, N., Mandić, D. 2011. "Bancassurance - New options for the development of Serbian financial sector." Facta Universitatis, Series: Economics and Organization 8(1): 15 - 29.

Munchen Re. 2001. "Bancassurance in Practice.” www. munichre.com, pp.19.

National Bank of Serbia (NBS). 2018. "Insurance sector in Serbia Third Quarter Report 2018." Accessed 01.05.2019, retrieved from https://www.nbs.rs/internet/english/60/60_6/insurance_III_2018.pdf.

National Bank of Serbia (NBS). Supervisory Board of Financial Institutions. 2016. «Sector for Supervision of the Performance of Insurance Activities." Accessed 28.04.2019, retrieved from https://www.nbs.rs/internet/cirilica/60/60_2/index.html.

National Mortgage Insurance Corporation (NKOSK). n.d. Available at http://www.nkosk.rs/en

Nissim, D. 2010. Analysis and Valuation of Insurance Companies, Center for Excellence in Accounting \& Security Analysis, Accessed May 3, 2019 retrieved from http://www.columbia.edu/ dn75/Analysis\%20and\%20Valuation \%20of $\% 20$

Njegomir, V., Maksimović, R. 2009. "Risk Transfer Solutions for the Insurance Industry.” Economic Annals January March 2009, LIV(180): 57-90.

Official Gazette RS, no. 107/2005

Official Gazette RS, no. 55/2004

Ostojić, S. 2014. "Global Trends in the Insurance Market and the Functioning of the Insurance Market in Serbia." Strategic Management 19(3): 18-30.

Schlag, C. 2003. "Determinants of demand for life insurance products - Theoretical concepts and empirical evidence." Swiss Re Economic Research \& Consulting, Accessed 02.05.2019, retrieved from https://pdfs.semanticscholar.org/eae1/b6be73e7f4bffc67e7d6fe7b99a794553844.pdf .

Serbian Export Credit and Insurance Agency (AOFI). n.d. Available at https://www.aofi.rs/en/. 